\title{
Fighting the rules of the game
}

\section{Nairobi, Kenya}

ANIMAL geneticists in Kenya, in collaboration with colleagues in the United States, Denmark and other African countries, have embarked on an ambitious programme to attempt to preserve the genetic diversity of Kenya's wild animals. The wildlife genetics programme, organized by the National Museums of Kenya, with the Kenya Wildlife Service, has begun in response to changing wildlife management policies that regard wild animals as an economic resource and to changing social attitudes that regard zebras, gazelles, elephants and others as pests.

\section{IMAGE UNAVAILABLE FOR COPYRIGHT REASONS}

Pests? Wild animals risk becoming an expendable commodity under Kenya's new rules.

Rashid Aman and Pieter Kat, wildlife geneticists at the Kenya Museums, hope to collect tissue samples from animals as they move or are moved around the country in order to keep track of species integrity and species mix. The programme was initiated as the two collaborated with Oliver Ryder of the Center for Reproduction of Endangered Species at the San Diego Zoo in California. The Kenyan Museums' Institute of Primate Research bought modern equipment with a grant from the European Communities. Ryder then amplified those funds with grant money from the Pew Charitable Trusts and the John and Beverly Stauffer Foundation to help establish in Kenya the laboratory techniques for growing cell lines for chromosomal analysis, DNA amplification and PCR analysis. The institute's first tissue sample came from the ear of a wounded elephant that had been treated by Wildlife Service veterinary surgeons.

Since then, Aman and Kat have added tissue samples from other elephants, wild dogs, cheetahs and bovid species. Meanwhile, Ryder is teaching techniques for genetic analysis to a Kenyan researcher who is visiting his San Diego laboratory. At the Institute of Population Biology in Copenhagen, Denmark, two Kenyan technicians have recently completed a threemonth training course in PCR and sequencing techniques. The Danish institute is collaborating with Aman and Kat on a study of interspecies genetic variation in bovids and intraspecies variation of bovids and elephants.

The need for wildlife genetics has become acute because Kenya is making plans to encourage game ranching, as well as big-game hunting. With 70 per cent of the country's wild animals living on private land - and an increasing attitude that they have to pay for their existence or be destroyed - the government recently approved a policy to allow people with permits to crop (raise, kill and the sell meat of wild animals that are not endangered, such as zebras and gazelles. Twenty-five businesses have applied for permits, apparently hoping to copy the success of Kenya's current game ranch (the Hopcraft Ranch) which has made a name for itself selling the meat of giraffes, zebras, Thomson's and Grant's gazelles to the Carnivore, a well-known Nairobi restaurant that also serves vegetarian fare.

The new policy allows people to kill animals on their property for private use; it also permits the sale and transport of wild animals from one ranch to another.

Some people in Kenya are lobbying the government for the return of big-game hunting, while ranchers, whose crops are destroyed by elephants and whose cattle are attacked by hyenas and lions, want the government to corral such wild beasts into fenced national parks.

Either way, the natural traffic of wild animals will be affected. Hence the desire to gather crucial genetic information, about susceptibility or resistance to disease for instance, for the long-term success of animal conservation.

Despite good intentions, Aman has met resistance from animal welfare advocates who complain that the loud dart guns used to stun animals before obtaining tissue samples frighten elephants and other animals. Customs agents, who hold radioactive isotopes in custody so long that they are no longer scientifically useful, are another difficulty.

Nevertheless, the wildlife geneticists intend to prevail. They are now hoping to expand into informal collaborations with the many scientists who visit Kenya to study its wildlife. The Kenya Wildlife Service is beginning to ask such visiting researchers, as a condition for permission to work in Kenya, to collect samples for the wildlife genetics programme.

Jane Stevens

\section{Tokyo quake}

Tokyo

ToKyo's 12 million residents were abruptly woken in the early hours of Sunday morning ( 2 February) by one of the biggest earthquakes to hit the city in several years. No serious damage occurred, but the earthquake has drawn attention to an unpredictable type of earthquake that can strike directly beneath the city at any time.

The quake, which measured 5.7 on the Richter scale, hit at 4:04 am with an epicentre about $90 \mathrm{~km}$ below Tokyo Bay next to the city. The earthquake occurred in a zone where three tectonic plates converge beneath the city. The Philippine Sea plate plunges below the Eurasian plate, on which Tokyo rests, at a depth of about $30 \mathrm{~km}$. And the Philippine Sea plate is in turn underridden by the subducting Pacific plate at even greater depth.

Tokyo and surrounding areas have an extensive network of seismometers and other equipment run by various government agencies to try and predict major earthquakes. But the network is designed primarily to predict the so-called Tokai earthquake, which is expected to strike at any time along the edge of the Philippine plate in Suruga Bay about 120 km southwest of Tokyo. The network may also pick up precursors of a great earthquake in adjacent Sagami Bay, the site of the Great Kanto Earthquake of 1923 which destroyed much of Tokyo and Yokohama.

But even the most optimistic seismologists in Japan accept that prediction of earthquakes in the zone of three converging plates beneath Tokyo is beyond the present capabilities of science. These "directly underneath" or chokka-gata earthquakes, although generally not as large as the big Suruga or Sagami Bay earthquakes (which measure $\mathbf{7 . 5}$ to 8.0 on the Richter scale), can be devastating if they occur at shallow depth. Fortunately, Sunday's earthquake occurred deep down at $90 \mathrm{~km}$. David Swinbanks

\section{CHINESE SCIENCE}

\section{Academy grows younger}

\section{Beijing}

ThE Chinese Academy of Sciences, the country's leading academic body, this month elected 210 new members, bringing its total complement to 515 and reducing the average age of its members from 75 to 69. The youngest of the new members is Zhao Yu-Fen, a 42-year-old woman chemist from Qinghua University. The election is the first since 1980, and marked the end of a 13-month selection process. Candidates were suggested by China's universities and research centres, and voted for by the academy's existing members. Like the Academy of Sciences in the former USSR, the Chinese Academy runs a large number of its own research institutes. You Qin $\mathrm{Li}$ 